\title{
Technological Empowerment of Rural Women for Sustainable Livelihood Security
}

\author{
Mayuri Bora $^{1^{*}}$ and Manoshi B. Deka ${ }^{2}$ \\ ${ }^{1}$ All India Coordinated Research Project-Home Science-Extension Component, \\ Department of Extension Education and Communication Management, \\ AAU, Jorhat, Assam PIN-785013, India \\ ${ }^{2}$ Department of Extension and Communication Management, $A A U$, \\ Jorhat, Assam PIN-785013, India \\ *Corresponding author
}

A B S T R A C T

\section{Keywords}

Indian extension system, Role, KVK,

Technological empowerment, Women

\section{Article Info}

Accepted:

15 March 2020 Available Online: 10 April 2020
Technological empowerment of women enables them in creating sustainable and diversified livelihood opportunity. Such diversification of livelihood is extremely necessary to escape many adverse situations. District based institution, Krishi Vigyan Kendra (KVK) has been imparting vocational trainings as an approach for technology transfer. The present study was conducted to assess whether there was adequate representation of women in such training programmes conducted by KVKs of Assam. A questionnaire was used for collecting the data from the selected KVKs functioning under Assam Agricultural University, Jorhat. Participation of women in vocational trainings with minimum three days duration for the period of $12^{\text {th }}$ Five Year Plan was analysed. Among the total participants, 53.55 per cent were male and 46.45 per cent were female. It was found that in some subject areas, there were only women participants i.e. hundred per cent participants were women where as in some other areas there was nil participation. Similarly the KVK wise analysis of data reflected a large variation among the KVKs.

\section{Introduction}

Technological empowerment of women has large potential to create a pool of human resources who are capable of ensuring livelihood security for themselves and for their family. Though Doubling farmers' Income by 2022 has become a highly cherished dream of Government of India there has been growing apathy among the farmers towards farming. In a study conducted by the National Sample Survey (2010), it was found 
that over 45 per cent of farmers wanted to quit farming. In a separate study conducted by The Centre for Study of Developing Societies (2014), 76 per cent farmers revealed that they would prefer to do some other work than farming. The root of such apathy of the farmers originates from weather-dependent farming systems, underdeveloped physical infrastructures for farming, biophysical difficulties including unseasonal rains, droughts and floods which are liable for repeated losses. The issue of livelihood of these farmers' family undoubtedly creates a serious concern. While supporting the farmers to cope with such uncertainties by formulating different programmes including crop insurance; women may be technologically empowered by exposing them to different agro based and allied technologies. Such technologies may support them in creating diversified livelihood and may support the family in sustainable livelihood. Such diversification of livelihood is extremely necessary to escape the zero income state of a family especially during adverse bio-physical situation and resultant crop failure. The technologies, which are expected to generate livelihood opportunities, should be transferred directly to the women clientele so that they can imbibe the intricacies of these technologies. District based institution KrishiVigyanKendra (KVK) has been working towards technology transfer and thereby reducing time lag between generation of technology at the research institution and its application by the ultimate users through different extension activities. At present 716 KrishiVigyanKendras are working as a part of Indian extension system throughout the country and these KVKs are being guided and coordinated by Indian Council of Agricultural Research and 11 Agricultural Technology Research and Application Institutions. The Annual report, DARE-ICAR, 2018-19 reflects that, in the year 2018-19, 14.98 lakhs participants were trained covering diverse target groups e.g. farmer, farm women, rural youth and extension personnel by the KVKs. Likewise 6262 training courses were organized for skill development of 1.64 lakh participants, out of which 36.26 per cent were women.

As a mandated activity, KVK conducts capacity building exercises or training programmes for different target groups including farmers, field extension personnel and rural youths and rural women. These training programmes are effective means of technology transfer. Trainings are conducted either for transferring scientific knowledge or for skill development of the participants with emphasis on "learning by doing". The trainings which focus practical application of the learnt skills are called 'vocational training'. Vocational trainings are generally less concerned with theory and such trainings may enable the clientele to start some ventures which may result in livelihood security and thereby improving the socioeconomic status. Keeping it in mind the present study was designed to explore whether there is adequate representation of women as participants in the vocational trainings organized by KVKs of Assam. It is noteworthy that, The National Women Empowerment Policy 2001 envisaged equal access to vocational guidance for women. The study will answer whether such advocacy are given proper weightage by the extension system of India or not.

\section{Materials and Methods}

The study was carried out in the state of Assam where 23 numbers of KVKs are functioning under administrative control of Assam Agricultural University, Jorhat. Seventeen KVKs, out of 23 which had completed at least five years were selected to fulfil the objective. One questionnaire was constructed for collecting the data on 
participation of women during 12th five year plan period (2012-17) i.e. for five years. The vocational trainings with minimum duration of three days were considered for the study. Data were collected on number of training programmes conducted for dissemination of different technologies and subject area wise participation of women. Collected data were analysed KVK wise and subject area wise and in terms of percentage of women in the respective categories.

\section{Results and Discussion}

\section{Women participation in vocational training}

It is observed from the table 1 that the selected seventeen KVKs conducted 379 numbers of vocational trainings and a total of 10,940 participants had participated in these training programmes. It is seen from the table 1 that highest number of training was conducted on mushroom cultivation i.e. It was found that highest numbers (890) of women were trained in 'food processing and preservation' trainings followed by training on 'mushroom cultivation' (804) and 'garment construction' (413).Women participation in vocational training was 46.45 per cent against 53.55 in case of men(Illustration I). Though extent of women participation in vocational training was found to be slightly lower than men, it is nearly satisfactory. Perhaps, liasioning with different stake holders e.g. District Agriculture Office, District Veterinary Office, District Fishery Office, District Industries and Commerce Centre, State Institute of Panchayat and Rural Development, NABARD, National Rural Livelihood Mission, different NonGovernmental organizations helped the KVKs in selecting interested trainees who had been in contact with such offices or agencies. Government of India's focus on skill development initiative might have sensitised different personnel at different levels who might triggered motivation among women clientele for attending vocational trainings at
KVKs. Moreover, implementation of Tribal Sub Plant and allocation of fund under the sub plant might have some impact on extent of women participation in Vocational trainings conducted by the KVKs. Besides, each KVK was supposed to adopt at least one village as model village for achieving the target of doubling farmers' income by 2022 and different programmes were carried out for inclusive uplift of these village families. This might be one of the reasons for women's satisfactory level of participation in vocational trainings conducted by KVKs.

\section{Subject area wise participation of women}

Illustration II shows that vocational trainings were conducted in thirty three (33) different areas by the 17 selected KVKs. Highest number of training was conducted on 'Mushroom cultivation'(43) followed by 37 numbers of training on 'Food processing and preservation' and 36 numbers of training on 'vermi-compost production'. A very few number of training was conducted on 'fodder management', 'goatery management', 'mali training' and 'Use and Application of ICT'. The table shows that largest number of participants was in entrepreneurship development training which was 1203 followed by mushroom cultivation which covered 1138 participants. Table 1 reveals men women comparison in participation and found that extent of women participation was highest in 'utilization of waste material' with 100 per cent followed by 'Dyeing and Printing', 'Garment construction' and 'Weaving' with 99.7, 99.5 and 99.1 per cent respectively. Likewise in 'food processing and preservation' women participation was 92.0 and trainings on, 'banana fibre extraction', 'sericulture' and 'rural craft', percentage of women participant was found to be more than 80.00 and in training on 'fodder management', and training on 'mushroom production' women participation was more than 70.00 per cent. 
Table.1 Subject wise women participants covered under vocational trainings

\begin{tabular}{|c|c|c|c|c|c|c|c|}
\hline \multirow{2}{*}{$\begin{array}{l}\text { Sl. } \\
\text { No. }\end{array}$} & \multirow[t]{2}{*}{ Area of vocational training } & \multirow{2}{*}{$\begin{array}{c}\text { No. of } \\
\text { trainings } \\
\text { conducted } \\
\text { by the } \\
\text { KVKs }\end{array}$} & \multicolumn{2}{|c|}{ Male } & \multicolumn{2}{|c|}{ Female } & \multirow[t]{2}{*}{ Total } \\
\hline & & & number & $\begin{array}{c}\text { \%age to } \\
\text { the row } \\
\text { total }\end{array}$ & number & $\begin{array}{c}\text { \%age to } \\
\text { the row } \\
\text { total }\end{array}$ & \\
\hline 1 & Food processing and preservation & 37 & 68 & 7.10 & 890 & 92.90 & 958 \\
\hline 2 & Mushroom & 43 & 334 & 29.35 & 804 & 70.65 & 1138 \\
\hline 3 & Garment Construction & 19 & 2 & 0.48 & 413 & 99.52 & 415 \\
\hline 4 & Dyeing and printing & 14 & 1 & 0.29 & 344 & 99.71 & 345 \\
\hline 5 & Water Hycinth & 14 & 3 & 0.91 & 326 & 99.09 & 329 \\
\hline 6 & Rural craft & 13 & 50 & 15.53 & 272 & 84.47 & 322 \\
\hline 7 & Entrepreneurship development & 24 & 962 & 79.97 & 241 & 20.03 & 1203 \\
\hline 8 & Water management & 5 & 225 & 54.48 & 188 & 45.52 & 413 \\
\hline 9 & $\begin{array}{l}\text { Horticultural Nursery } \\
\text { Management }\end{array}$ & 34 & 711 & 80.70 & 170 & 19.30 & 881 \\
\hline 10 & IFS & 23 & 595 & 76.38 & 184 & 23.62 & 779 \\
\hline 11 & Vermicompost & 36 & 701 & 81.61 & 158 & 18.39 & 859 \\
\hline 12 & Weaving & 5 & 1 & 0.87 & 114 & 99.13 & 115 \\
\hline 13 & Poultry/Duckery & 10 & 110 & 45.83 & 130 & 54.17 & 240 \\
\hline 14 & Sericulture & 6 & 12 & 10.43 & 103 & 89.57 & 115 \\
\hline 15 & Bee keeping & 11 & 167 & 64.73 & 91 & 35.27 & 258 \\
\hline 16 & Value addition to meat and fish & 6 & 68 & 37.57 & 113 & 62.43 & 181 \\
\hline 17 & Utilization of waste material & 3 & 0 & 0.00 & 77 & 100.00 & 77 \\
\hline 18 & Piggery & 6 & 136 & 65.38 & 72 & 34.62 & 208 \\
\hline 19 & $\begin{array}{l}\text { Production technology of } \\
\text { vegetable and flower }\end{array}$ & 9 & 186 & 65.03 & 100 & 34.97 & 286 \\
\hline 20 & Banana Fiber & 3 & 14 & 19.44 & 58 & 80.56 & 72 \\
\hline 21 & Fish farming & 17 & 377 & 86.27 & 60 & 13.73 & 437 \\
\hline 22 & Carpet making & 2 & 2 & 3.77 & 51 & 96.23 & 53 \\
\hline 23 & Fodder management & 1 & 6 & 22.22 & 21 & 77.78 & 27 \\
\hline 24 & Goatery Management & 1 & 26 & 61.90 & 16 & 38.10 & 42 \\
\hline 25 & Scientific dairy farming & 6 & 101 & 87.83 & 14 & 12.17 & 115 \\
\hline 26 & Scientific Banana cultivation & 3 & 77 & 84.62 & 14 & 15.38 & 91 \\
\hline 27 & Oil palm cultivation & 10 & 291 & 95.72 & 13 & 4.28 & 304 \\
\hline 28 & Seed production & 5 & 108 & 90.00 & 12 & 10.00 & 120 \\
\hline 29 & Tea husbandry & 4 & 205 & 93.61 & 14 & 6.39 & 219 \\
\hline 30 & Mali training & 1 & 44 & 89.80 & 5 & 10.20 & 49 \\
\hline 31 & Coconut production & 4 & 187 & 93.03 & 14 & 6.97 & 201 \\
\hline 32 & Use and application of ICT & 1 & 40 & 100.00 & 0 & 0.00 & 40 \\
\hline \multirow[t]{2}{*}{33} & Market advisory & 3 & 48 & 100.00 & 0 & 0.00 & 48 \\
\hline & Total & 379 & 5858 & 53.55 & 5082 & 46.45 & 10940 \\
\hline
\end{tabular}

Source: Secondary data from KVK 
Table.2 KVK wise women participation in vocational training programmes compared to men participation

\begin{tabular}{|c|c|c|c|c|c|}
\hline \multirow[t]{2}{*}{ Name of KVK } & \multicolumn{2}{|c|}{ Male } & \multicolumn{2}{|c|}{ Female } & \multirow{2}{*}{$\begin{array}{c}\text { Total } \\
\text { number }\end{array}$} \\
\hline & Number & $\begin{array}{c}\text { Percentage } \\
\text { to the row } \\
\text { total }\end{array}$ & Number & $\begin{array}{c}\text { Percentage } \\
\text { to the row } \\
\text { total }\end{array}$ & \\
\hline KVK Sibsagar & 26 & 20.16 & 103 & 79.84 & 129 \\
\hline KVKSonitpur & 265 & 26.32 & 742 & 73.68 & 1007 \\
\hline KVKDhemaji & 169 & 30.84 & 379 & 69.16 & 548 \\
\hline KVKNalbari & 395 & 36.81 & 678 & 63.19 & 1073 \\
\hline KVKDarrang & 267 & 35.94 & 476 & 64.06 & 743 \\
\hline KVKGolaghat & 42 & 45.65 & 50 & 54.35 & 92 \\
\hline KVKDhubri & 376 & 49.93 & 377 & 50.07 & 753 \\
\hline $\begin{array}{l}\text { KVKKarbi } \\
\text { Anglong }\end{array}$ & 81 & 52.60 & 73 & 47.40 & 154 \\
\hline KVKJorhat & 261 & 53.05 & 231 & 46.95 & 492 \\
\hline KVKBarpeta & 299 & 54.96 & 245 & 45.04 & 544 \\
\hline KVKChirang & 152 & 56.93 & 115 & 43.07 & 267 \\
\hline KVKKarimganj & 187 & 57.01 & 141 & 42.99 & 328 \\
\hline KVKKokrajhar & 404 & 59.94 & 270 & 40.06 & 674 \\
\hline KVKTinsukia & 248 & 58.35 & 177 & 41.65 & 425 \\
\hline KVKCachar & 502 & 64.11 & 281 & 35.89 & 783 \\
\hline KVKNagaon & 629 & 74.09 & 220 & 25.91 & 849 \\
\hline KVKKamrup & 1555 & 74.80 & 524 & 25.20 & 2079 \\
\hline Total & 5858 & 53.55 & 5082 & 46.45 & 10940 \\
\hline
\end{tabular}

Source: Secondary data from KVK 
Illustration.1 Participation of women in skill development/vocational training programmes conducted by KVK during 2012-13 to 2016-17

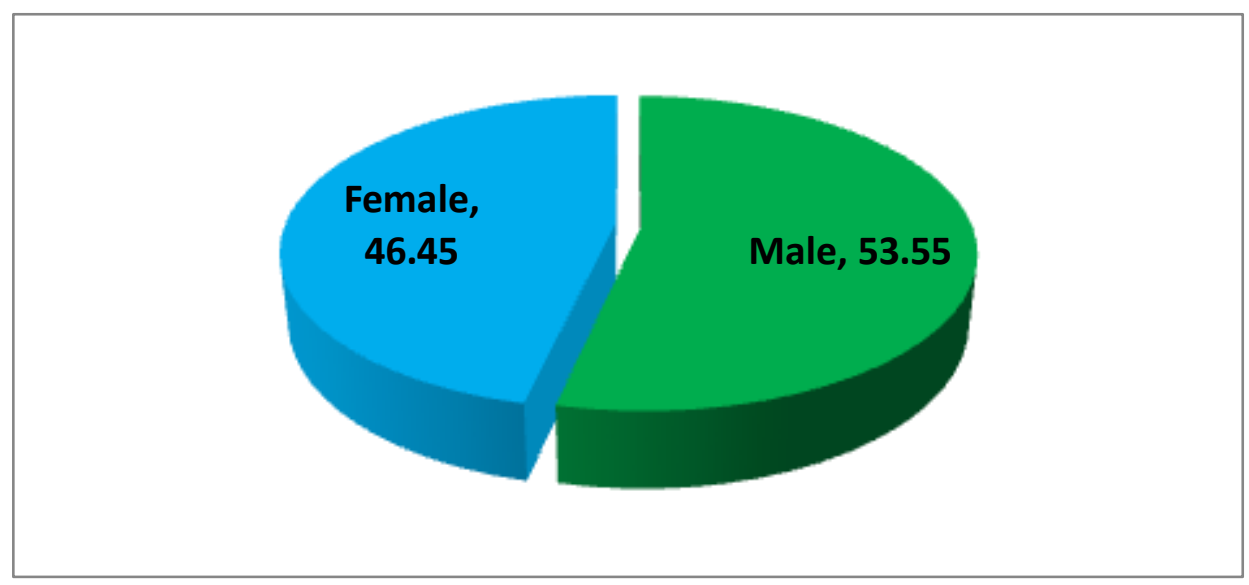

Total participants: 10940 Source: Secondary data from KVK

Illustration.II Subject wise number of vocational training programmes conducted by KVKs

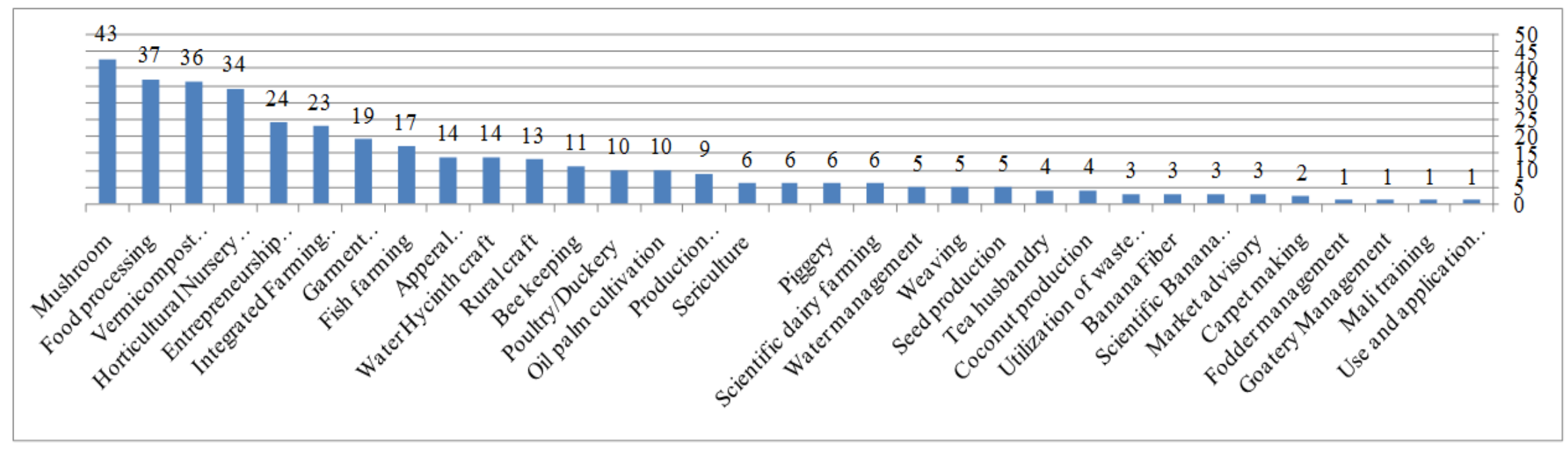

Total Participants: 10940

Source: Secondary data from KVK 
Illustration.III KVK wise comparison of women participation in vocational training programmes

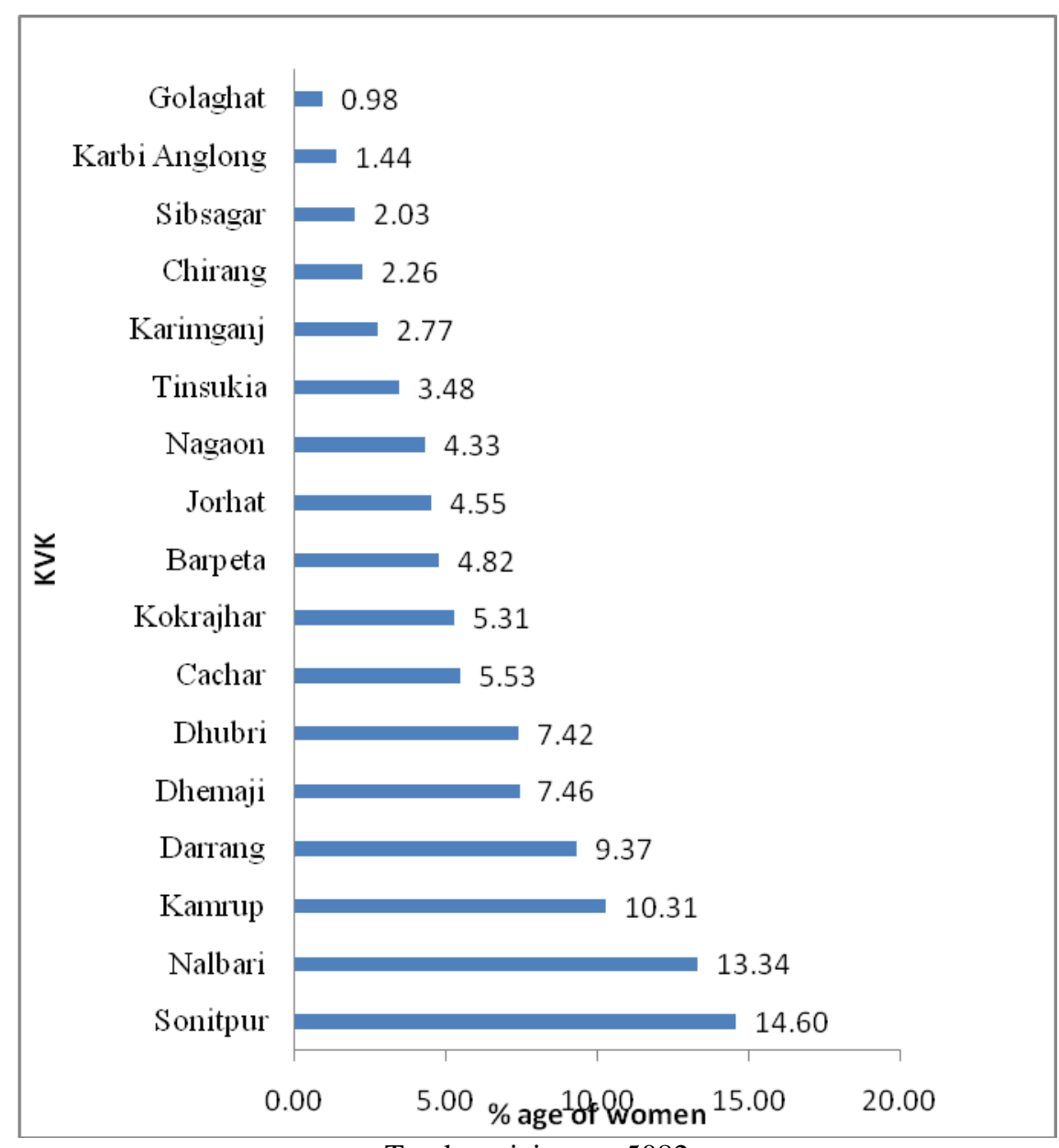

Source: Secondary data from KVK

In an study conducted by Seema K. et. al at KVK, Purnea, Bihar, it was found that in the training on 'mushroom cultivation' there were 399 beneficiaries out of which 298 were women comprising $74.86 \%$ of the total participants whereas there were 102 men participants comprising about $25.56 \%$ among total participants during the study period, i.e. 201314 to 2016 17. That shows that in some areas including mushroom production women surpasses men participants. On the contrary, no participation of women was found in two areas i.e. 'Market advisory' and 'Use and application of ICT'. In the present day context these two trainings are very essential for the women, as these may help them in marketing their produce. In the last couple of years many marketing applications were designed for the smooth marketing of the rural products. Moreover, Social media have become a good platform for advertising by the all producers. Training on such areas may be of great help for the women clientele.

\section{KVK wise comparison of women participation in vocational training programmes}

Table 2 shows that women participation was highest in KVK Sibsagar with 78.63 per cent 
followed by KVK Sonitpur with 73.68 per cent. Conversely, KVK Kamrup included 25.20 per cent women in their vocational trainings with lowest percentage followed by KVK Nagaon with 25.91 per cent which was second lowest among all KVKs. Similarly, if it is observed from the illustration III that out of total 5082 women participants, KVK Sonitpur covered 14.60 per cent whereas KVK Golaghat covered very negligible percentage of women participant. It may be interpreted that the inclusion of women in the vocational trainings was not uniform among the districts rather it showed a large variation among the KVKs. In conclusion, the study shows a judicious trend of women participation in the vocational trainings conducted by KVKs. And that is how it may be interpreted that the extension system of India is instrumental in giving technological exposure to the women folk. However, their exposure to different technologies varies largely. Likewise, the percentage of women participation also varies from lowest 25.20 per cent to 78.60 per cent from among the KVKs. It reflects that as such there is no guideline available regarding minimum number of participants to be covered by each KVK and under each training programme.
Though trainings are conducted on the basis of training need assessment of the participants, there should be some guidelines on coverage of women participation by each KVK and under each subject area.

\section{References}

Kumari, Seema., Akhtar, Nadeem., Kumar Santosh., (2018). Role of KrishiVigyan Kendra in women empowerment through mushroom production technology. Journal of Agricultural \& Environmental Research, 1(1): 1-5.

DARE-ICAR (2018-19). Annual Report 2018-19. Ministry of Agriculture \& Farmers Welfare. Government of India.

The Centre for Study of Developing Societies. 2014. State of Indian Farmers. Delhi https://www.downtoearth.org.in/news/in dias-deepening-farm-crisis-76-farmerswant-togive-up-farming-shows-study43728. Retrieved on 25/10/17.

NSSO, 2010.http://www.thehindubusiness line.com/todayspaper/45-of-farmerswant-toquit-farming-swaminathan/ article1030041.retrieved 24/10/2017.

\section{How to cite this article:}

Mayuri Bora and Manoshi B. Deka. 2020. Technological Empowerment of Rural Women for Sustainable Livelihood Security. Int.J.Curr.Microbiol.App.Sci. 9(04): 1942-1949. doi: https://doi.org/10.20546/ijcmas.2020.904.231 